\title{
THE DEVELOPMENT OF THE DELTA AND BRAJDICA AREAS IN POST-WWII RIJEKA: BETWEEN VISION AND REALITY
}

\author{
A B S S T R A C
}

The municipal amalgamation of Rijeka and Sušak in the post-WWII period opened the question of the spatial and functional integration of the two previously independent towns. The Delta and Brajdica areas, reclaimed from the sea in the mid-1800s to accommodate harbour and railway facilities, were regarded as valuable spatial resources for locating the administrative, cultural, recreational and commercial services befitting the new metropolis. The article will present the urban planning documents and the (un)realized projects designed for the transformation of the Delta and Brajdica areas during the 1940s and 1950s that revealed the growing gap between the urban planners' aspirations and the realities of those times. 


\section{DELTA AND BRAJDICA AS UNTAPPED POTENTIAL FOR URBAN REGENERATION}

Advantageously situated on the north-eastern Adriatic coast, the city of Rijeka experienced a mostly steady urban and demographic growth from the 1800s onwards stimulated by considerable industrial and trade investments. Having inherited a reputable maritime and industrial tradition, Rijeka is still perceived as a relatively prosperous and business-oriented centre, despite its delayed and limited adaptation to the socio-economic realities of the post-socialist and post-industrial era. In the last decades, a reduction or complete shutdown of the activities of the large manufacturing companies that formed the backbone of Rijeka's economy (the paper mill, the oil refinery, the shipyards, the metalworking industry), left certain city sectors in functional and physical decay and in need of reinvention. Among them are the Delta and Brajdica areas - the in-filled terrain at the mouth of the Rječina river comprising approx. 16 hectares of industrial landscape dominated by warehouses, openair timber storages, parking lots, waste-management and harbour facilities etc., in different conditions and with varying intensity of contemporary use. Due to its exceptional geographical position between two historic city cores (the Old Town of Rijeka and downtown Sušak), its spaciousness, a potentially attractive waterfront, and no historically significant buildings under state protection (a virtual "blank slate"), Delta has been recognised as one of the most valuable spatial resources for advancing Rijeka's cultural, residential, commercial, and recreational capacities. In recent years, the redevelopment of Delta was a subject of numerous city-initiated workshops and projects, such as PATCHing the City: the Public L (2011), the international competition for Delta and Porto Baroš (2013), and the Sweet and Salt segment of the Rijeka2020 - European Capital of Culture project (2016), engaging the professional community and the wider public in an on-going discussion about its future.

Considering the current efforts for the reintegration of Delta and Brajdica into the urban context, the history of the area is, in some aspects, surprisingly under-researched. While there are numerous historical analyses of its initial formation and the subsequent expansions and usage for harbour activities, hardly any published material can be found that delves deeper into the evaluation of the post-WWII period. Therefore, the ambition of this paper will be to formulate a coherent narrative of the (un)realised development plans during the first post-war decades (the 1940s to mid-1960s). The research was mainly conducted using primary historical sources (urban plans, building permits and other public records) preserved in the State Archives in Rijeka and in the Archives of Yugoslavia in Belgrade, along with articles in professional 
magazines (Arhitektura, Čovjek i prostor) and local newspapers (Primorski list, Riječki list, Novi list) that proved vital for gaining insight into the planning processes and the often diverging opinions of urbanists and government officials. What will hopefully become apparent from the interpretation of the findings is that these decades hold the key to understanding not only Delta and Brajdica's current conditions, but also the common historical roots of all the contemporary urban reclamation plans.

\section{INTRODUCTION :}

\section{A BRIEF HISTORICAL OVERVIEW OF THE AREAS' URBAN DEVELOPMENT UP UNTIL THE $1940 \mathrm{~S}$}

The status of a free port given to Rijeka in 1719 by king Charles VI and the following influx of substantial capital from all over the Habsburg Empire and abroad, instigated the transformation of Rijeka's seashore to accommodate a large and modern harbour, equipped to handle the traffic of the trade companies and service the manufactures and factories sprouting on its outskirts. Between 1850 and 1855 , a major infrastructural investment was undertaken to divert and extend the bed of the Rječina river in order to eliminate the risk of flooding. The abandoned riverbed Mrtvi kanal (Dead Canal) was filled with sea water and used for mooring small vessels and sailboats. The space flanking the Mrtvi kanal and the new Rječina flow was gradually covered to obtain extra surfaces for cargo storage and the accommodation of the network of railway tracks connecting the port to the Zagreb-Budapest railway line. This artificial island was named Delta because of its resemblance to the Greek letter, while the patch of land on the eastern bank of the Rječina, also filled multiple times, retained the historical toponym Brajdica (derived from brajda, meaning "vineyards"). During the Hungarian governance of Rijeka (1868-1918), Delta and Brajdica were exclusively designated for the handling and storage of timber, while a small dock basin (Porto Baross) was built to facilitate its transshipment. ${ }^{1}$ At the turn of the century, a new settlement of Sušak was established on a narrow plateau along the eastern bank of the Rječina. The burgeoning community will profit greatly from the changed political circumstances in the inter-war period, namely, from the municipal independence obtained in the newly-founded Kingdom of Serbs, Croats and Slovenes (later named Kingdom of Yugoslavia). In the 1920s and 1930s, the state border between the kingdoms of Italy and Yugoslavia split the town down the middle leaving Rijeka and Sušak, with their corresponding ports, in different countries. While Rijeka was stagnating under the Fascist Italian rule, Sušak thrived in an environment of open rivalry, 
its port's performance and traffic almost matching that of its neighbour. Delta and Brajdica (belonging to the Sušak port) expanded their capacities with the installment of new warehouses under concession to various private entrepreneurs, thus functioning as a modern timber terminal. ${ }^{2}$ The optimism, ambition and self-esteem of inter-war Sušak was channelled into the drawing up of the General Regulation Plan in the late 1930s which, although never implemented due to the onset of WWII, would have a great impact on the future of Delta.

FORMULATING AN IDEA OF THE PUBLIC DELTA AND

BRAJDICA: URBAN PLANS AND SPATIAL INTERVENTIONS

BETWEEN 1940-1955

General Regulation Plan of Sušak:

negotiating a compromise

As mentioned previously, Sušak managed to develop a General Regulation Plan just before the beginning of the war, through an open competition conducted in 1936. The winning proposals submitted by Croatian architects, pre-eminently ardent promoters of the Modernist movement, were considered as guidelines for preparing the final draft approved by the authorities in $1940 .{ }^{3}$ Although ineffectual, the plan had far-reaching consequences on post-war urban planning of the joint Rijeka-Sušak municipality. Especially indicative was the recognition of Delta and Brajdica as valuable spatial resources for broadening the city centre. The main points were: (1) the functional zoning of Delta and Brajdica, i. e. their division into northern and southern parts, the former to be reserved for public and the latter for port/industrial use; (2) a rather dense urbanization of northern sections for the purpose of housing new commercial and transport services, interspersed with residential areas, public squares and open markets; and (3) the establishment of a new port facility (a timber terminal) in Martinšćica bay, at the easternmost administrative border of Sušak, to compensate for the reduced output of Delta and Brajdica. The city planners and officials tried to navigate the challenges of improving the citizens' well-being while not constraining the economic development in the process. The result was a compromise, a quid pro quo: a partly public Delta and Brajdica in exchange for Martinšćica. This negotiation of a middle-ground would be a recurring theme in post-war planning documents, though the economic interests would almost always trump any other considerations. 
The 1945-1948 interregnum:

envisioning a united city of Rijeka-Sušak

The towns of Rijeka and Sušak were briefly reunited during WWII under the Italian (1941-1943) and German occupation (1943-1945). The Italian experts utilized this opportunity to sketch a radical proposal for filling in the entire Mrtvi kanal and building a set of enclosed city blocks on a moderately regular grid across the northern Delta. The merit of their idea was discussed, but ultimately rejected in the aftermath of the war, when urbanists were again faced with the question of the physical integration of the two towns. ${ }^{4}$ The political uncertainty over the claims on Rijeka was resolved at the Paris Peace Conference in the autumn of 1946, in favour of the Federal People's Republic of Yugoslavia making it possible for Rijeka and Sušak to officially merge into a single administrative unit by the spring of 1948. In spite of the extensive war damage to the port's infrastructure, the reconstruction started almost immediately and with unprecedented speed. ${ }^{5}$ The local architects and urbanists from Rijeka and Sušak's former Civil Engineering Offices, together with their colleagues employed in the ministries in Zagreb, worked wholeheartedly to articulate strategies for a functional, smooth, and permanent merging of the town's halves. Their solutions tackled the practical problems while simultaneously addressing the symbolic, more intangible repercussions of this historic transition. The first (and best) example of their forwardlooking attitude was the construction of the so-called "symbiotic bridges" over the Rječina river in 1946, at the location of the inter-war border crossing. The pressing task was to re-establish the traffic routes interrupted after the demolition of the bridges connecting Delta to the mainland, but the realised composition of a 25-metre-wide pedestrian bridge and an adjacent narrower one for motor transport was anything but unambitious and pragmatic. (Fig. 1) This new spacious link between the opposite riverbanks demonstrated a bold political statement of unity (the erasing of the old divisions once and for good), while at the same time resolving the problem of Rijeka's constant deficit of places for larger public gatherings. The lucid design of the bridges was a joint endeavour of skilled architects and engineers (Kruno Tonković, Zdenko Strižić, Božidar Rašica, Zdenko Kolacio, Davor Schwalba, Max Pecs), and their execution rested on the cooperation of building firms, local manufacturing companies, citizen donations etc. ${ }^{6}$

While the construction of the symbiotic bridges was under way in 19461947, the Department of Civil Engineering of Rijeka (Zdenko Kolacio, Davor Schwalba and collaborators) took on the assignment of drafting an outline of 
the new general urban plan of Rijeka-Sušak and its environs, that would provide the basis for the Directive Regulative Plan of Rijeka-Sušak cities finished in 1948 (Antun Ulrich and Branko Vasiljević, Urban Planning Institute of the Socialist Republic of Croatia, Zagreb). Both plans offered a more balanced distribution of the city territory between different stakeholders, taking into account the citizens' right to recreational areas (waterfronts, walkways, parks), housing estates located away from major pollutants and an accessible, lively central district (the City) with cultural, educational, commercial and entertainment amenities. Instead of seeing the area of Delta and Brajdica as an obstacle, a wedge driven between the two already formed city cores, they decided to regard it as an advantage, a readily available space for taking on new functions. The first plan/sketch placed the demarcation line between the Upper (city-administered) and Lower (port-administered) Delta and Brajdica at the envisioned thoroughfare linking the Rijeka National Theatre with downtown Sušak (the Piramida), therefore moving it a bit more to the south of what the inter-war regulation plan of Sušak would have permitted. The loss of some of the storage space would again be compensated by a new port basin in the Martinšcica bay, an idea that the responsible authorities were willing to consider, but the main stumbling block was to be the elimination of the railway grid running through the port system, for the purpose of freeing up the Delta area for development, and the comprehensive (and costly) railway bypass that was to be built to connect the Martinšćica port. ${ }^{7}$ The Directive Regulative Plan elaborated more on this aspect, recommending a complete removal of all railway infrastructure in the broader city centre (from Žabica to Martinšćica). The railway detour would answer all of the port's transportation needs and enable the building of new quays and smaller production plants in Martinšćica and further along the eastern coast to the Bakar Bay. By clearing the port facilities from Delta and Brajdica, a proper city waterfront could be opened up and enough space provided for an ambitious building program of diverse solitary structures immersed in greenery. An added bonus would be the articulation of a complex transit hub around Žabica Square, including a railroad terminal, an intercity bus station and a maritime terminal. (Fig. 2) The authors suggested a step-by-step implementation of this proposal, aware of the domino effect it would have on Rijeka's entire coastal stretch, as it would force some of the standing land occupants to relocate permanently. ${ }^{8}$ As the consulted authorities were ready to make very few concessions, in particular the departments of maritime affairs and the railway and port management, the regulation was never confirmed by the Rijeka City Council. The case of the Directive Regulative Plan illustrates the mounting opposition local urban planners were faced with when trying to influence the inherited mindset. The 


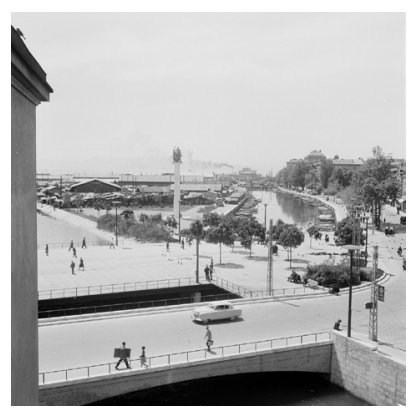

Figure 1 . The bridges over the Rječina river with the Liberation Monument and the Mrtvi kanal in the background. Foto: Benko, 1955, Croatian State Archives in Zagreb

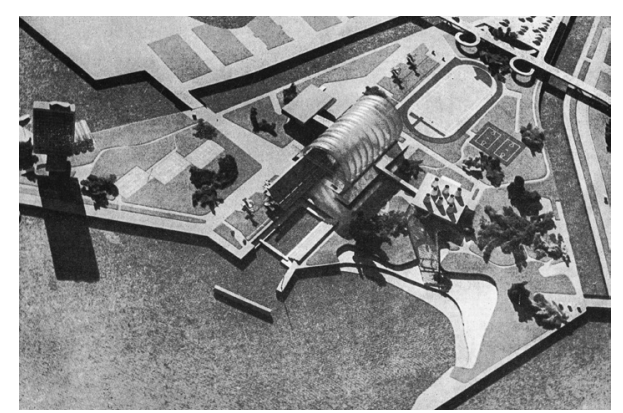

Figure 3. Vladimir Turina's unrealized project for the Combined Swimming Centre Rijeka-Sušak, 1949, published in the journal Urbanizam i arhitektura, Zagreb, 1950

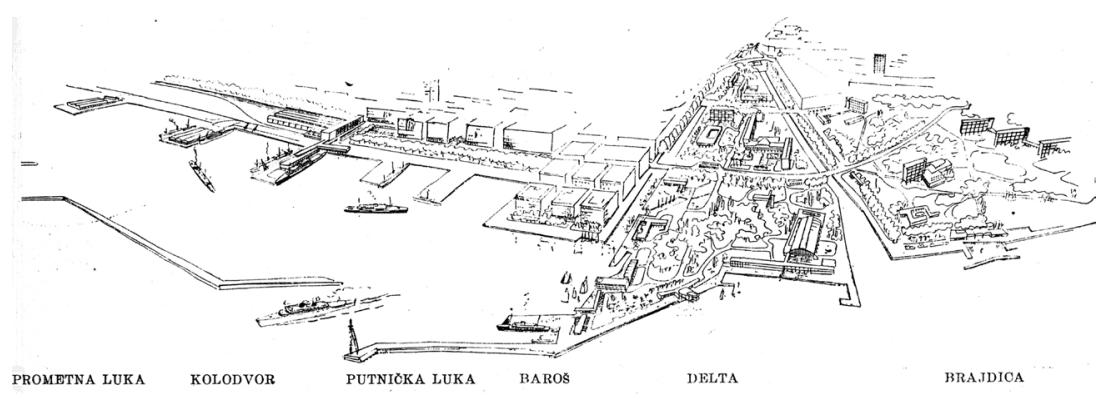

Figure 2. The transformation of the city centre proposed by the Directive Regulative Plan of Rijeka-Sušak cities of 1948. Published in the journal Arhitektura, Zagreb, 1949

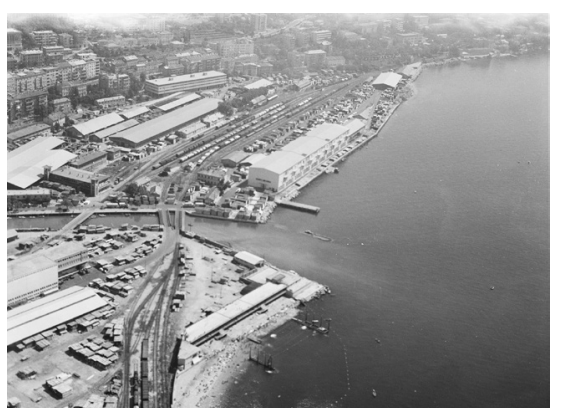

Figure 4 . The water sports complex in the southeast Delta with the warehouses in the South Brajdica in the background. Foto: Rendulić, 1965

Croatian State Archives in Zagreb

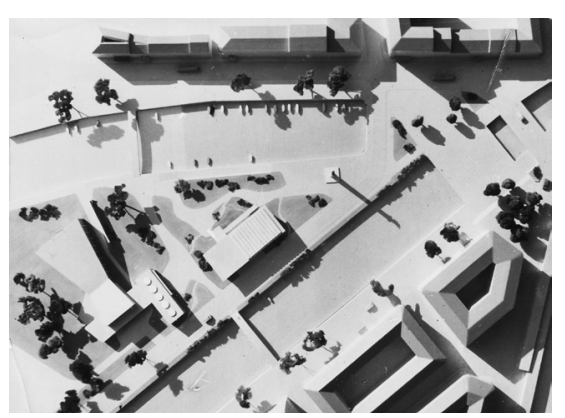

Figure 6. Zdenko Kolacio and Zdenko Sila's outline for the urbanisation of the Upper Delta, 1952, State Archives in Rijeka

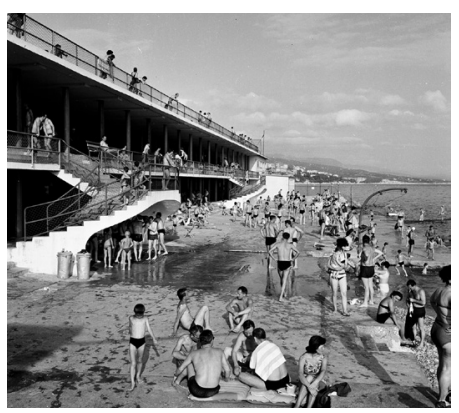

Figure 5 . The bathing edifice in the southeast Delta before its demolition in the late 1960s. Foto: Pintar, 1964. Croatian State Archives in Zagreb 
critiques aimed at the status quo were readily discarded, which diminished the possibility for a creative reimagining of the city's identity and stilted its physical transformation.

\section{Vladimir Turina's Combined Swimming Centre}

Rijeka-Sušak: vision vs. the art of the possible

The ideation of Rijeka's new urban matrix, avidly discussed in the architectural circles of the late 1940s, intrigued architect Vladimir Turina to such an extent that he, together with his assistants (Radić, Kučan, and Seifert), decided to join the debate with an unique proposal for a combined swimming centre in Delta. The project was so courageous in form and content, so visually striking and inspiring, that it became the most iconic representation of Delta's potential. The many technologically avant-garde characteristics of Turina's design, for instance the kinetic construction of the swimming pool's stands and the conical ventilation shafts on the restaurant's rooftop, resonated with the optimistic, self-confident post-war atmosphere. ${ }^{9}$ When we concentrate on the urbanistic qualities of the project, particularly the land partition and disposition of motorways, we notice that Turina engaged polemically with the Directive Regulation Plan. He did away with the notion of the road stretching through Delta (the National Theatre-Piramida thoroughfare), as it was, in his opinion, making the middle section less flexible for future construction and suggested instead the building of a viaduct in Upper Delta with nearby multi-storeyed parking garages. (Fig. 3) More important was the conceptual shift towards Delta as the recreational, leisure and entertainment heart of the unified RijekaSušak cities, reserved for the citizens' enjoyment and participation in various sports activities and events. The non-utopian character of the design (since Turina had made the blueprints detailed and technical enough to be executed in the not-so-distant future), made it virtually timeless, thus still influential and unavoidable in contemporary discussions about Delta's redevelopment.

The central features of Turina's proposal were the swimming pools with a movable, cylindrical roof adaptable to the changing of seasons. This was not an arbitrary choice, since Turina took his cue from the then current lobbying efforts to locate the new swimming pool at the southernmost part of Delta. The idea was initially put forward in 1947 after the financing was secured through the first Five-Year Plan. Delta was chosen to in order to favour neither the Rijeka nor the Sušak side, as a neutral territory suitable for the gradual and seamless integration of the two recently joined municipalities. The building program entailed the erection of several recreational facilities expected to meet the needs of local sports clubs (the swimming and rowing teams) and the 
building of a 33x18-metre enclosed swimming pool with heating installations and the option of using either sea or salt water. ${ }^{10}$ The project counted on the infrastructure already present at the building site (the rowing club, bathing structures etc.), but the prevailing factor was not entirely economic. It had more to do with preserving the the previous generations' habitual use of space and, therefore, with strengthening the claim for a more public access to Delta. ${ }^{11}$ Unfortunately, the execution came to a partial halt because of a land ownership dispute forcing the city planners to relocate the swimming pool to Pećine, and when that site proved inadequate, to settle for building it next to the late 19th century public bathhouse in Školjić. As for the planned water sports complex in south Delta, it was reduced in scope to fit in the small building plot in the southeast corner, just below the bundle of railroad tracks. This triangularly shaped patch allotted to the Sušak municipality back in the 1920s was to be transformed during the 1950s to house several modestly sized facilities, such as the Primorje members' club house, an enclosed rowing hall for the winter months, a boat warehouse and a storage for miscellaneous equipment. (Fig. 4) Since the wooden bathing edifice dating from the 1920s was deemed unsalvageable after the assessment of the war damage, it was replaced with a more durable, spacious and modern reinforced-concrete structure featuring a flat roof for sunbathing, terraces that could double as stands for watching water polo matches and memorable curved staircases leading to approximately 400 changing rooms. ${ }^{12}$ (Fig. 5) At the height of its popularity in the $1950 \mathrm{~s}$, it serviced up to 3000 guests a day in the peak summer months, testifying to the citizens' readiness to embrace the potential of urban beaches and seaside entertainment. The unwillingness on behalf of the port and railway authorities to relinquish their ownership rights to a larger part of Delta made it impossible to tap into that existing interest and cultivate it further. Comparing this makeshift recreational zone to Turina's megaproject for Delta would, of course, be unflattering and ultimately misguided, but it serves as a reminder of the chasm between the aspirations and the realities of those times, between the ideals and the art of the possible.

The Liberation Monument and other projects for Upper Delta between 1952-1955

A viable chance to reclaim Upper Delta arose in 1952 with the competition for a monument honouring the tenth anniversary of the liberation of Rijeka. Advocating for submissions that would skilfully blend the sculptural and urbanistic elements of the design and leaving the choice of the location to the contestants, the competition presented an opportunity for local urbanists and architects Zdenko Kolacio and Zdenko Sila to propagate the agenda of the public 
Delta. Teaming up with Rijeka's foremost sculptor Vinko Matković, they put forward the plans for a 14-metre-high obelisk supporting an allegorical bronze group of a female personification of victory flanked by two soldiers. Placed at the top of the Delta, overlooking the Mrtvi kanal and the pedestrian bridge over the Rječina, it would add a much-needed focal point to the area, while also enforcing the politically desirable theme of the liberation and unification of Rijeka and Sušak in the socialist Yugoslavia. ${ }^{13}$ Their entry comprised additional visualisations of the monument's wider urban setting. Concretely, the authors sketched two solitary buildings on a plateau then occupied by piles of timber and dilapidated warehouses: an aquarium and a multifunctional exhibition hall, surrounded by public parks and intimate pedestrian walkways. (Fig. 6) They hoped that the pressure of marking the upcoming jubilee, coupled with the derelict state of Upper Delta incongruous with its political connotations, could instigate a stronger public support for its complete reinvention. The competition jury recognized and endorsed their broader objective by rewarding their work with the first prize. The Upper Delta project gained traction with the local media. Models and descriptions were published trying to convey to the wider audience the benefits of its implementation, in terms of both a more aesthetically pleasing city centre and a promise of new leisure, educational and commercial activities. The sea water flora and fauna aquarium was the most talked about, probably because the Oceanographic Institute had been campaigning for its construction in Rijeka for years. ${ }^{14}$ By using the competition as a pretext for the Upper Delta reconstruction proposal, the city planners achieved an important goal of continuing the public debate on this topic. Unfortunately, the political and financial backing of the project quickly waned or, more accurately, had just enough stamina to follow through on the erection of the monument by the spring of 1955, leaving the more complex and resource-intensive aspects for an undetermined future. Edo Jardas, the mayor of Rijeka, in an interview for Riječki list in 1953, revealed his scepticism about Delta being transferred under the city's jurisdiction any time soon and a personal conviction that it should continue to serve the interests of trade and industry. ${ }^{15}$

\section{ACCELERATED DEVELOPMENT BETWEEN 1955-1965: PRAGMATISM PREVAILS}

The 1957 partial regulation plan of Delta and Brajdica

The unveiling of the Liberation Monument in early May 1955 made even more apparent the run-down and unhygienic look of the Delta area congested with stacks of wooden pallets, discarded building material, dilapidated sheds and 
timber depots. (Fig. 1) The current conditions were unbecoming of Rijeka's status as the administrative centre of the Upper Adriatic and the main transit spot for domestic and international tourists. Polishing the town's image and ensuring a more rational land use were the key arguments for re-examining the urban plans generated in the past decade in order to set up a new course of action. The deciding factor, however, was the long-awaited court ruling in favour of the district of Rijeka, by which it gained property rights over the Delta and Brajdica area and the registration of a new legal entity responsible for renting out individual lots to companies in the trade and transport business. In accordance with the new management model, the Town Planning Institute of Rijeka (director: Zdenko Sila) produced a study of the partial regulation plan of Delta and Brajdica in 1957, whose directives were affirmed in the draft of the 1962 General Urban Development Plan of Rijeka and later documents. ${ }^{16}$ The regulation plan adopted a pragmatic approach to the issue of reconciling the requirements of the modern city with the uninterrupted growth of port services. A new zoning scheme was articulated to facilitate the separation between the North/Upper Delta and Brajdica (the grounds north of the National Theatre-Piramida line), reserved for mixed-use development, and the South Delta and Brajdica intended for the construction of modern warehouses. Some overlapping would occur in the middle zone, where the planners predicted the erection of provisional buildings, such as open-sided hangars and office spaces. By the mid-1960s, most of the projects featured in the regulation plan's booklet were realized according to plan or slightly modified, whereas new investments in warehouse space and clean industries were accommodated. The physiognomy of Delta and Brajdica shaped during those few years changed little until the early 1990s, making those years the most intense period in the area's history.

The modernisation of the port facilities in South Delta and Brajdica

The spacious terrains in South Delta and Brajdica were traditionally exploited for temporary storage and manipulation of timber. The unsystematic use of land and loss of merchandise due to harsh weather had a negative effect on the daily port operations and overall productivity. The substantial financial commitment of several large import-export companies in the late 1950s initiated the modernisation of this zone, comparable to the building expansion that the Rijeka harbour went through at the turn of the century. Although the architecture of the warehouses was primarily subjected to the criteria of practicality and feasibility, making aesthetic considerations secondary, the overall appearance of Delta and Brajdica was undoubtedly improved by the 
new investments. The aforementioned middle zone of Delta was given a tidier look by lining rows of hangars with open or closed peripheral walls. The same investor, Exportdrvo, leased the parcels parallel to the railway tracks and commissioned projects for several canopied open-air storages and one larger, multi-level warehouse constructed on a rectangular layout with interior steel construction. ${ }^{17}$ (Fig. 7) Further to the east, Istravinoexport commenced the twophase erection of the $6000 \mathrm{~m}^{2}$ warehouse and bottle-filling facility designed by Lavoslav Horvat, the leading Croatian expert in industrial architecture. ${ }^{18}$ The massive, introverted and imposing edifice was somewhat opened up by the numerous window perforations on the north, town facing façade, displaying the architect's awareness of the sensitive urban setting of the interpolated building. (Fig. 8) Across the bridge over Rječina, more canopied storages were put up alongside the railroad tracks. They were used by rentiers such as Slovenijales and Drvošped who set up the local branches' headquarters in the nearby office building on Andrija Kačića Miošića Promenade. ${ }^{19}$ Gradšped and the Directorate for Raw Materials in Belgrade owned the two most prominent warehouses in Brajdica. These elongated, multi-storeyed structures in reinforced and prestressed concrete, intended for longer detention of commodities and office use, were designed by the Rijeka-based engineer Mate Senjanović and have greatly increased the storage capacity of the port zone. ${ }^{20}$ (Fig. 4)

\section{The Upper Delta and Brajdica: the future postponed}

The Upper Delta and Brajdica, now under the partial jurisdiction of the local authorities, seemed destined to start the long-anticipated urban renewal process founded on the principles proclaimed in the post-war regulations: public control of planning and execution, multi-faceted and citizen-oriented content, horticulturally nurtured open spaces etc. The vision of Upper Delta as a public park with a few solitary buildings (aquarium, exhibition venue) was publicized on numerous occasions in the mid-1950s, capturing the public's imagination. The regulation study of 1957 only strengthened those aspirations by adding a new town library to the list. By 1960, there were at least two preliminary projects circulating around the city planning departments: the aquarium building by architect Andrija Čičin-Šain, and the Workers' University, a collaborative work by Milena Frančić-Sulovsky, Tanja Lučić and Vlado Sulovsky. The latter was thought of as an ambitious solution to Rijeka's chronic lack of purpose-built spaces for educational and cultural activities. Centrally positioned on the Delta plateau, with an unusual six-sided ground plan, the Workers' University would be an instant landmark and a meeting place for inhabitants from both sides of the city. Providing a comfortable and flexible frame for housing many functions (the city library, cinema and concert auditorium, lecture halls, study rooms 


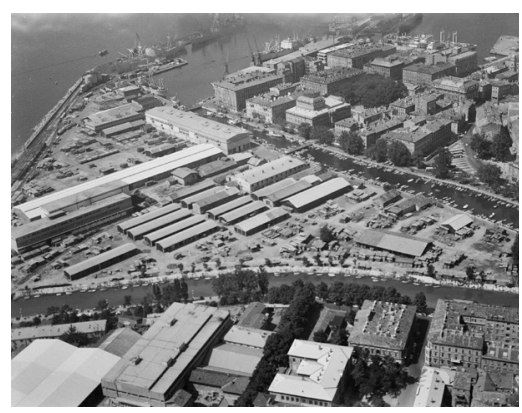

Figure 7. The view of the South Delta with the Exportdrvo warehouse parallel to the Mrtvi kanal and the Istravinoexport facility in the southeast corner. Foto: Rendulić, 1965, Croatian State Archives in Zagreb

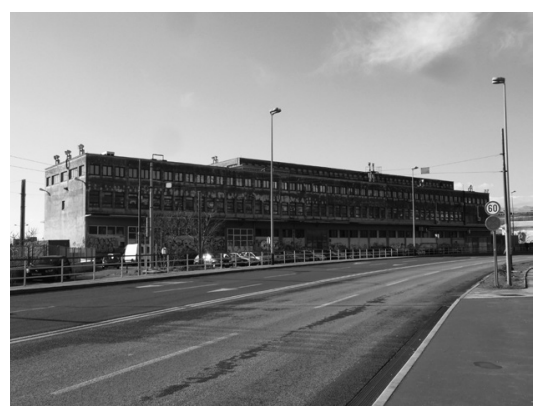

Figure 8. Lavoslav Horvat's Istravinoexport warehouse and bottle-filling facility in the South Delta, the current condition. Foto: Lidija Butković Mićin, 2015

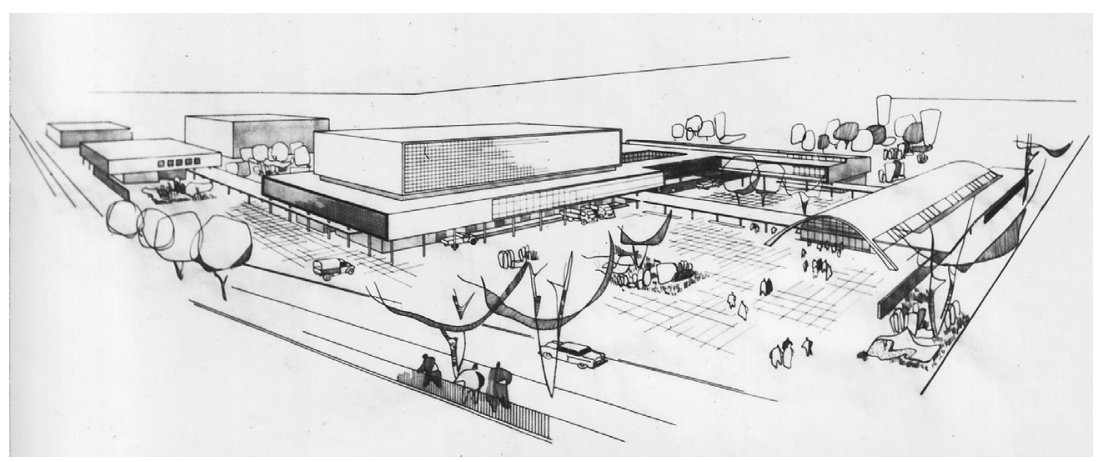

Figure 9. Dušan Marčeta and Vlado Sulovsky's competition project for the Opće trgovačko poduzeće warehouse/department store in the Upper Brajdica, 1956, State Archives in Rijeka

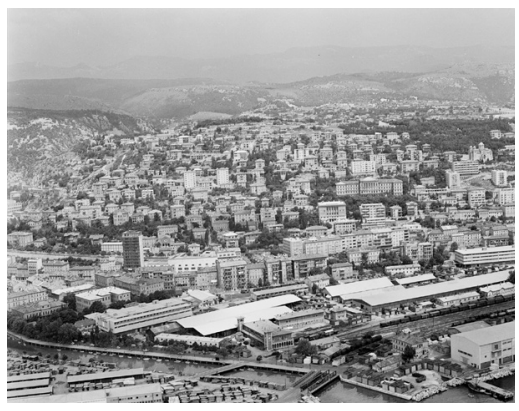

Figure 10. The Opće trgovačko poduzeće warehouse adjacent to the downtown area of Sušak and other storage facilities in the Upper Brajdica. Foto: Rendulić, 1964, Croatian State Archives in Zagreb 
etc.), it could have conformed well to the changing demands of the growing metropolis. ${ }^{21}$ In the next few years, more suggestions have been considered, for instance, the new Assembly Hall, a sports centre and a contemporary art gallery, but without any visible progress. Meanwhile, the urban planners invested their efforts in an attempt to clean up the Brajdica area, that is, the strip of land bordering the downtown Sušak that had steadily been overbuilt with provisional warehouses, trading stalls and storage facilities. The urban renewal of this fairly unstructured zone would imply turning it into the new business and commercial centre of the eastern part of town, in continuation of the strategy laid out by the inter-war Sušak municipality. A competition was held in 1956 to obtain designs for the warehouse of a wholesale company (Opće trgovačko poduzeće), to be situated in a prominent location close to the banks of the Rječina and the pedestrian promenade. The competition conditioned a more representative outer appearance befitting the building's surroundings, and a flexible ground plan so it could be easily extended and converted into a modern department store at a future date. The competition was, of course, intended to be a compromise between the immediate needs of the investor and the planned revitalisation of the area. The winning project by Dušan Marčeta and Vlado Sulovsky certainly fulfilled this requirement, but the detailed implementation plan from a few years later, according to which the warehouse was realised in 1961, had very little in common with it. Where the former envisioned the department store to be an attractor that could potentially foster a broader regeneration of Brajdica, the executed project altered the building to better suit its main function as a storage facility and did away with the pleasant and ample public spaces. ${ }^{22}$ (Figure 9, 10) The story of this project is paradigmatic of the constant limitations, setbacks and disappointments city planners were coming across in those decades when trying to negotiate the enforcement of the regulation plans.

\section{DISCUSSION AND CONCLUSIONS}

Most of Rijeka's present-day coastline was artificially created during the nineteenth century in service of the mercantile interests of the AustroHungarian Empire, Delta and Brajdica being the largest territory reclaimed from the sea to accommodate harbour and railway installations. Prior to the 1940 s, the area was valued solely for its spaciousness and revenue potential, and extensively used for the provisional storage and transshipment of timber, with minimal investments made in modern port mechanisation and warehouse capacities, excluding Porto Baross. Peripheral to the city centre of Rijeka, Delta and Brajdica were more indispensable to the up-and-coming town of 
Sušak, whose urban expansion and economic prosperity depended on their unimpeded exploitation and transformation. The General Urban Development Plan of Sušak affirmed the desire to weave them more efficiently into the urban fabric, articulating the standpoint that will become even more relevant in the post-war period, after the municipal amalgamation of Rijeka and Sušak.

In the first regulation plans of the late 1940s, Delta and Brajdica were pinned for an intense urbanisation not only because of their new position in-between the two city centres, but because of the scarcity of flat terrain, in general due to the topographical features of the region. By locating the major administrative, communal, recreational and other buildings there, the urban planners sought to solve two problems at once: that of the harmonious integration of Sušak and Rijeka and that of the advancement of public services befitting the new metropolitan centre of the Upper Adriatic. The latent (and sometimes overt) conflicts over land distribution and governance among the city, port and railway authorities dwarfed the initial projects and/or discouraged their implementation. The ratification of regulation documents was often deferred because the stakeholders couldn't reach a compromise or there wasn't sufficient political will to change the status quo. After the 1957 regulation study reduced the claims to just the Upper Delta and Brajdica (and even that was open to reconsideration), no attempts were made to extend the city functions further. The exception was the southeast tip of Delta where the swimming and sports facilities were put together for public use. In the late 1950s, the port authorities commenced the comprehensive redevelopment of South Delta and Brajdica, which resulted in the erection of half a dozen modern warehouses and numerous open-air hangars, of which the Istravinoexport by Lavoslav Horvat was architecturally the most accomplished. ${ }^{23}$ While this area enhanced its productivity and gained a more orderly appearance, its northern counterpart remained virtually unchanged because of the lack of public or private ventures. When an investor did make a commitment, like in the case of the local wholesale company and its warehouse/department store, the original building project was eventually scaled down and divested of any placemaking potential.

The ensuing planning documents, including the General Urban Development Plan of Rijeka accepted in 1974, retained the conservative strategy of the 1960s by keeping the agreed-upon demarcation line between the city and port jurisdictions. A novel element appeared in the 1971 Detailed Plan for the Central Area of Rijeka drafted by Sharkland Cox \& Associates of London in collaboration with the Town Planning Institute of Rijeka, and financed by the United Nations Development Programme as part of the Upper Adriatic project. Focusing on the coordination of the growing city traffic, the plan designated 
large parking surfaces surrounding the city core, Upper Delta and Brajdica being the prime candidates. The former was converted to a car park in the late 1970s, a role it still holds day and will for the foreseeable future. The 1980s brought an ambitious open competition for the urban development of almost the entire area, which revived public interest in this matter, but was destined to remain only on paper because of the deepening economic and political crisis preceding the dissolution of SFR Yugoslavia. ${ }^{24}$ In the meantime, the port authorities acted independently of these plans, advancing with the realisation of the container terminal in Brajdica and extending the shoreline for that purpose, as well as building the waste management and water supply facilities in the South Delta in the early 1990s. The completion of the Memorial Bridge over the Mrtvi kanal in 2001 (3LHD architects) marked the first milestone of Delta's integration into the urban tissue since the Liberation Monument was constructed half a century ago, and currently the last one, since the propositions of the General Urban Development Plan of 2007 and the Rijeka Gateway project have yet to be fulfilled.

The contemporary situation could best be described as a prolonged "inbetween" state of the coinciding dissolution of the former spatial and functional matrix and advent of a new policy of (public) use. This precarious position, nevertheless, allows room for reflection and invites historical research to help figure out the future course of action. The explored period between 1940 and 1965 should be considered especially important in that regard for a number of reasons: (1) it proposed amendments to the traditional land use in order to benefit the public interest; (2) in doing that, it deconstructed the outdated notion of Rijeka's monofunctional identity; and (3) it tried to untwine Rijeka's sense of self-worth from its status as a maritime and industrial centre, by (4) instigating a long-term negotiation process between all parties with a vested interest in the coastline and the adjacent land. The strategies, promoted during these decades, of achieving a more balanced relationship between the public and economic interests could still inform future transformations of the Delta and Brajdica areas. The diapason of possible strategies ranged from Turina's vision of "building with emptiness" (Green Delta) to the full urbanisation (the City) on the opposite side of the spectrum. There are also lessons to be learned from the period's failure to realise the majority of its aspirations, the constant stalling and indecisiveness, the vicious circle of coming to a dead end and returning to the drawing board. This continuous loop of starting optimism followed by growing scepticism, frustration, disappointment and then back again is all too familiar. It remains to be seen if by re-examining the past, borrowing fresh ideas from it or letting go of certain inherited misconceptions, it was finally to be broken. 
Radmila Matejčić, Kako čitati grad (Rijeka: Izdavački centar Rijeka, 1990), 181-186; József Berkes, "Izgradnja riječke luke od 1968. do 1918.," in Ervin Dubrović (ed.), Riječka luka: povijest, izgradnja, promet (Rijeka: Municipal Museum, 2001), 133-164; Dražen Hrešić, "Uz izgradnju, miniranje i obnovu luke," in Ervin Dubrović (ed.), Riječka luka: povijest, izgradnja, promet, 165-180; Nana Palinić, "Traffic Service Buildings-Railway and Port,” in Daina Glavočić (ed.), Architecture of Historicism in Rijeka: 1845-1900 (Rijeka: Museum of Modern and Contemporary Art, 2002), 374-419.

Marijan Bradanović, "Graditeljstvo Sušaka između dva svjetska rata," in Berislav Valušek (ed.), Moderna arhitektura Rijeke (Rijeka: Museum of Modern and Contemporary Art, 1996), 112-147; Julija Lozzi Barković, Moderna arhitektura Rijeke i Sušaka (Rijeka: Adamić, 2015), 404-421. The second prize was awarded to Velimir Jamnicky and his collaborators Mirko Premužić and Zdenko Kolacio, and three third awards went to Juraj Neidhardt, Vlado Antolić and Vasa Teodorović respectively. Jamnicky was officially employed on drafting the final version of the General Regulation Plan of Sušak., Lozzi Barković, Moderna arhitektura Rijeke i Sušaka, 59-69. The decision to preserve the Mrtvi kanal was motivated by practical reasons (its capacity for docking smaller boats), and aesthetic considerations (picturesque appearance). Gradski narodni odbor Rijeka 1945.-1947., Folder 41, State Archives in Rijeka

The post-war assessments of Rijeka and Sušak ports concluded that out of 8056 meters of coastline (quays, piers, and water breaks) only $904 \mathrm{~m}$ were operable. Around 50\% of the port's storage capacity was lost, most of the mechanisation was destroyed, and the railway installations were in need of serious reconstruction. Josip Kirinčić, „Tehnološki razvitak riječke luke,“, in Ervin Dubrović (ed.), Riječka luka: povijest, izgradnja, promet, 213-232; Andrea Roknić Bežanić, "Rijeka od oslobođenja 1945. do Pariškog mirovnog ugovora 1947. godine" (PhD diss., University of Zagreb, 2012), 123-125, 153-159.

Gradski narodni odbor Rijeka 1945.-1947., Folder 33, 41, 61, State Archives in Rijeka; Kruno Tonković, "Simbiozni mostovi na Rječini u Rijeci,“ Građevinar 1 (1968), 3-13; Maks Peč, "Glavni most na Rječini, “S Sušačka revija 6-7 (1994), 99; Milica Trkulja, Riječki mostovi (Rijeka: Municipal Museum, 1998), 89-91.

Gradski narodni odbor Rijeka 1945.-1947., Folder 81, State Archives in Rijeka; Ministarstvo pomorstva Vlade FNRJ 1946.-1953., Folder 73, Archives of Yugoslavia in Belgrade; Zdenko Kolacio, "Priprema se regulacioni plan za Rijeku, Sušak i okolicu," Primorski vjesnik, January 12,1947

Gradski narodni odbor Rijeka 1945.-1947., Folder 37, 81, State Archives in Rijeka; Ministarstvo pomorstva Vlade FNRJ 1946.-1953., Folder 73, Archives of Yugoslavia in Belgrade; Antun Ulrich and Branko Vasiljević, "Direktivna regulaciona osnova gradova Rijeka-Sušak," Arhitektura 1822 (1949), 47-50; Zdenko Kolacio, "Obnova i izgradnja Rijeke prema direktivnom generalnom regulacionom planu,“" Riječki list, March 14, 1948

Vladimir Turina, "Kombinirano plivalište Rijeka-Sušak," Urbanizam i arhitektura, 7-8 (1950), 37 45; Ante Marinović-Uzelac, Naselja, gradovi, prostori (Zagreb: Tehnička knjiga, 1986), 170-183; Hela Vukadin Doronjga, "Vladimir Turina” (PhD diss., University of Zagreb, 2012), 154-156.

Zdenko Kolacio made the preliminary drawings that illustrated the intended disposition of the new swimming pool. "Počinje izgradnja zimskog plivačkog bazena u našem gradu," Riječki list, September 27, 1947

11 The architect Zdenko Prikril designed the first permanent bathing structure erected in the southeast tip of Delta in the mid-1920s. This location was also used by the local rowing club and swimming team, although some problems occasionally occurred due to the pollution from the nearby industrial zone and the damage caused by the weather conditions., Mirjana Kos and Julija Lozzi Barković, Kvarnerska kupališna baština: nestala kupališta s kraja 19. i početka 20. stoljeća (Opatija-Rijeka: Croatian Museum of Tourism and State Archives, 2009), 124-126, 140-143. 
The ground plans for the newly built structures mostly were not preserved, with the exception of the winter rowing hall and the storage facility. Only the members' club house was not torn down to make room for later investments. Narodni odbor grada Rijeke 1948.-1955., Folder 26/51, Narodni odbor općine Sušak 1955.-1962., Folder 106, Građevinski arhiv Skupštine općina Rijeka 1945.1990., Folder 296, State Archives in Rijeka; "Nalazimo se pred otvaranjem kupališta na Delti," Primorski vjesnik, June 28, 1946

Daina Glavočić, "Vinko Matković (1911-1973): sušački kiparski opus," Sušačka revija 6-7 (1994), 53-58; Lidija Butković Mićin, "Istarsko-kvarnerski spomenici Zdenka Kolacija," Anali Galerije Antuna Augustinčića 32-33/34-35 (2012.-2015.), 283-298.

Viktor Križanec, „Potreba gradnje akvarija u Rijeci,“ Riječki list, November 22, 1952; „Kako će izgledati budućnost Delte?““ Riječki list, September 25, 1953; Viktor Križanec, „Da li će Rijeka dobiti morski akvarij,“ Novi list, October 13, 1954; "Kipar, ljevač i arhitekti o spomeniku,” Novi list, May 4, 1955; „Morski akvarij,“ Novi list, June 1, 1955

"Drug Edo Jardas o gradskim problemima,” Riječki list, October 1, 1953

Građevinski arhiv Skupštine općina Rijeka 1945.-1990., Folder 1306, State Archives in Rijeka; Srđan Škunca, "Pedeset godina urbanističkih planova grada Rijeke," Zbornik sv. Vida 5 (2000), 25-33.

The project documentation for these hangars and warehouses is only partially preserved. The canopied open-air storages were designed by Građevno-projektni zavod (architect Juračić) in 1953. The largest Exportdrvo's warehouse by Zagreb-based architect Slavko Novak was constructed in 1958/1959. Narodni odbor grada Rijeke 1948.-1955., Folder 152/53, Narodni odbor općine Sušak 1955.-1962., Folder 125, State Archives in Rijeka

Although the Istravinoexport warehouse in Delta was mentioned in the recently published comprehensive monograph on the oeuvre of Lavoslav Horvat, the attribution could be confirmed only after the original blueprints were uncovered in the State Archives in Rijeka. Narodni odbor općine Sušak 1955.-1962., Folder 165, State Archives in Rijeka; Zrinka Paladino, Lavoslav Horvat: kontekstualni ambijentalizam i moderna (Zagreb: Meandar media, 2013), 303.

The canopied warehouse for Slovenijales was designed in 1956 by Mate Senjanović and Andrija Čičin-Šain in the project bureau of the construction company Jadran in Rijeka, while the Drvošped company bought the building project from Metalna Maribor (architect Dolenjc, 1961). Narodni odbor općine Sušak 1955.-1962., Folder 125, 221, State Archives in Rijeka

Narodni odbor općine Sušak 1955.-1962., Folder 121, Građevinski arhiv Skupštine općina Rijeka 1945.-1990., Folder 780, State Archives in Rijeka Delti će se graditi nova zgrada Radničkog sveučilišta," Novi list, December 28, 1958; S. Škrbec, "Dom Radničkog sveučilišta," Novi list, May 13, 1959

Narodni odbor općine Sušak 1955.-1962., Folder 136, State Archives in Rijeka; Zdenko Kolacio, "Na Brajdici će se podići Veletrgovačka kuća," Novi list, March 31, 1956; Zdenko Kolacio, "Prilog uređivanju budućeg trgovačkog centra," Novi list, May 12, 1956

The Istravinoexport building is architecturally and historically valuable, perhaps not deserving of the highest protection status, but its retention in the future urban redevelopment plans would certainly be justified. See: Lidija Butković Mićin, "Zašto riječka industrijska baština propada?," Pogledaj.to, http://pogledaj.to/arhitektura/zasto-rijecka-industrijska-bastina-propada/ (accessed March 30, 2016).

The competition held in 1986 postulated an ambitious building programme that would substitute the existing port facilities with new commercial developments. The first prize was awarded to Tomislav Dolečki, Branka Kaminski, Neda Kaminski-Kirš and Antun Kirš.,"Delta i Brajdica u Rijeci: natječaj za urbanističko i arhitektonsko rješenje," Čovjek i prostor 422 (1988), 14-15. 
Berkes, József. "Izgradnja riječke luke od 1968. do 1918.," in Riječka luka: povijest, izgradnja, promet, edited by Ervin Dubrović, 133-164. Rijeka: Municipal Museum, 2001.

Bradanović, Marijan. "Graditeljstvo Sušaka između dva svjetska rata," in Moderna arhitektura Rijeke edited by Berislav Valušek, 112-147. Rijeka: Museum of Modern and Contemporary Art, 1996.

Butković Mićin, Lidija. "Istarsko-kvarnerski spomenici Zdenka Kolacija," Anali Galerije Antuna Augustinčića 32-33/34-35 (2012.-2015.): 283-298.

Butković Mićin, Lidija. “Zašto riječka industrijska baština propada?,” Pogledaj.to, http://pogledaj. to/arhitektura/zasto-rijecka-industrijska-bastina-propada/. Accessed March 30, 2016.

Glavočić, Daina. "Vinko Matković (1911-1973): sušački kiparski opus," Sušačka revija 6-7 (1994): 53-58.

Hrešić, Dražen. "Uz izgradnju, miniranje i obnovu luke." in Riječka luka: povijest, izgradnja, promet edited by Ervin Dubrović, 165-180. Rijeka: Municipal Museum, 2001.

Kirinčić, Josip. „Tehnološki razvitak riječke luke,“ in Riječka luka: povijest, izgradnja, promet edited by Ervin Dubrović, 213-232. Rijeka: Municipal Museum, 2001.

Kolacio, Zdenko. "Priprema se regulacioni plan za Rijeku, Sušak i okolicu.” Primorski vjesnik, January 12, 1947.

Kolacio, Zdenko. “Obnova i izgradnja Rijeke prema direktivnom generalnom regulacionom planu.“ Riječki list, March 14, 1948.

Kolacio, Zdenko. "Na Brajdici će se podići Veletrgovačka kuća.” Novi list, March 31, 1956.

Kolacio, Zdenko. "Prilog uređivanju budućeg trgovačkog centra." Novi list, May 12, 1956.

Križanec, Viktor. "Potreba gradnje akvarija u Rijeci.“ Riječki list, November 22, 1952.

Križanec, Viktor. „Da li će Rijeka dobiti morski akvarij.“ Novi list, October 13, 1954.

Kos, Mirjana, and Lozzi Barković, Julija. Kvarnerska kupališna baština: nestala kupališta s kraja 19. i početka 20. stoljeća. Opatija-Rijeka: Croatian Museum of Tourism and State Archives, 2009.

Lozzi Barković, Julija. Moderna arhitektura Rijeke i Sušaka. Rijeka: Adamić, 2015.

Marinović-Uzelac, Ante. Naselja, gradovi, prostori. Zagreb: Tehnička knjiga, 1986.

Matejčić, Radmila. Kako čitati grad. Rijeka: Izdavački centar Rijeka, 1990.

Paladino, Zrinka. Lavoslav Horvat: kontekstualni ambijentalizam i moderna. Zagreb: Meandar media, 2013.

Palinić, Nana. "Traffic Service Buildings-Railway and Port," in Architecture of Historicism in Rijeka: 1845-1900 edited by Daina Glavočić, 374-419. Rijeka: Museum of Modern and Contemporary Art, 2002.

Peč, Maks. "Glavni most na Rječini,“ Sušačka revija 6-7 (1994): 99.

Roknić Bežanić, Andrea. "Rijeka od oslobođenja 1945. do Pariškog mirovnog ugovora 1947. godine" PhD diss., University of Zagreb, 2012.

Škrbec, S. "Na Delti će se graditi nova zgrada Radničkog sveučilišta." Novi list, December 28, 1958.

Škrbec, S. "Dom Radničkog sveučilišta.” Novi list, May 13, 1959.

Škunca, Srđan. "Pedeset godina urbanističkih planova grada Rijeke," Zbornik sv. Vida 5 (2000): 13-49.

Tonković, Kruno. "Simbiozni mostovi na Rječini u Rijeci,“ Građevinar 1 (1968): 3-13.

Trkulja, Milica. Riječki mostovi. Rijeka: Municipal Museum, 1998.

Turina, Vladimir. "Kombinirano plivalište Rijeka-Sušak," Urbanizam i arhitektura, 7-8 (1950): $37-45$.

Ulrich, Antun, and Vaisljević, Branko Vasiljević. "Direktivna regulaciona osnova gradova RijekaSušak,“ Arhitektura 18-22 (1949): 47-50.

Vukadin Doronjga, Hela. "Vladimir Turina" PhD diss., University of Zagreb, 2012

"Delta i Brajdica u Rijeci: natječaj za urbanističko i arhitektonsko rješenje," Čovjek i prostor 422 (1988): 14-15. 
“Drug Edo Jardas o gradskim problemima.” Riječki list, October 1, 1953.

„Kako će izgledati budućnost Delte?.“ Riječki list, September 25, 1953.

"Kipar, ljevač i arhitekti o spomeniku.” Novi list, May 4, 1955.

„Morski akvarij.“ Novi list, June 1, 1955.

"Nalazimo se pred otvaranjem kupališta na Delti.” Primorski vjesnik, June 28, 1946.

"Počinje izgradnja zimskog plivačkog bazena u našem gradu." Riječki list, September 27, 1947.

Ministarstvo pomorstva Vlade FNRJ 1946.-1953., (Fond 552), Folder 73, Archives of Yugoslavia in Belgrade

Gradski narodni odbor Rijeka 1945.-1947., (Fond JU-212), Folder 33, 37, 41, 61, 81, State Archives in Rijeka

Narodni odbor grada Rijeke 1948.-1955., (Fond JU-16), Folder 26/51,152/53, State Archives in Rijeka

Narodni odbor općine Sušak 1955.-1962., (Fond JU-111), Folder 106, 121, 125, 136, 165, 168, 221, State Archives in Rijeka

Građevinski arhiv Skupštine općina Rijeka 1945.-1990., (Fond JU-169), Folder 296, 780, 1306, State Archives in Rijeka 


\section{KOMIKOPOLIS}

\section{Gențiana Cristina Dumitrașcu}

Arhitektonski prezentacija obuhvata jedan render ili seriju rendera, savršeni trenutak, predstavljajući idealizaciju još ne-realizovanog projekta. Šta bi se desilo ako bismo mogli saznati kako je projekat nastao, kako je svaki sloj dodavan dok nije postignut konačni oblik, a prikazani ljudi bi mogli da ispričaju arhitektonski priču?

Fleksibilni hibrid grafičkog medija stripova, koji u svojoj strukturi kombinuje narativni element, prostor i pokret, je oduvek imao jaku vezu sa pojmom arhitekture (simboličkog protagoniste ili čak centralne figure u stripovsko priči). Doktorska disertacija „Komikopolis - Alternativni način prezentacije, razmatranja i projektovanja arhitekture“ analizira kroz teorijske studije, intervjue i eksperimente način na koji karakteristični elementi stripa mogu poboljšati tradicionalnu arhitektonsku prezentaciju i način na koji se ostvaruje interakcija sa arhitekturom i procesom projektovanja prostora.

\section{KONCEPT NAPRAVE KAO ANALITIČKO SREDSTVO U ISTRAŽIVANJU ARHITEKTONSKOG KVIR PROSTORA \\ Branko Burmaz}

Postoje arhitektonske analize prostorne prakse koje se koriste konceptom arhitektonske strukture kao naprave za percepciju. Metafora naprave omogućava da se kombinuju statične reprezentacije prostora sa dinamičnim prostornim iskustvima. U istraživanju arhiektonskog kvir prostora, prostora koji je proizveden kroz samoorganizovane prakse i ignorisan od strane arhitektonske discipline, koncept naprave kao analitičkog sredstva kojim se suprotstavlja življeno i zamišljeno može biti od velike koristi. Ovde razmatram dve različite naprave. Jednu je koristila Beatriz Kolomina (Beatriz Colomina) u svojoj analizi rodnog prostora, nazivajući je naprava za uramljivanje, a druga naprava je naprava za orijentisanje iz „Kvir fenomenologije“ Sare Ahmed (Sara Ahmed). Ono što pokušavam da pokažem je da na početku procesa normalizacije arhitektura, funkcionišući kao naprava za percepciju, proizvodi kvir prostor simultanim mehanizmima uramljivanja i skrivaja, odnosno orijentisanja i dezorijentisanja. Snagom ovih naprava nastaje zjapeća podela u prostou i u društvu.

KLJUČNE REČI: ARHITEKTONSKI KVIR PROSTOR, NAPRAVA ZA URAMLJIVANJE/SKRIVANJE, NAPRAVA ZA ORIJENTISANJE/DEZORIJENTISANJE, PERCIPIRANI PROSTOR, NORMALIZACIJA PROSTORA, PODELA PROSTORA

\section{RAZVOJ PODRUČJA DELTE I BRAJDICE U RIJECI NAKON DRUGOG SVETSKOG RATA: IZMEĐU VIZIJE I STVARNOSTI}

\section{Lidija Butković Mićin}

Formalnopravno ujedinjenje Rijeke i Sušaka po završetku Drugog svetskog rata, u međuraću teritorijalno i upravno samostalnih gradova, nametnulo je pitanje prostornog i funkcionalnog povezivanja dvaju polutki grada. Područje Delte i Brajdice, postupno nasipavano od 1850-ih godina nadalje za potrebe lučkih i željezničkih postrojenja, percipirano je kao dragoceni prostorni resurs za lociranje zgrada administrativne i javne namene te kulturnih, rekreativnih i komercijalnih sadržaja, primerenih novom regionalnom središtu. Članak prezentira urbanističke planove te (ne) realizirane arhitektonske projekte za transformaciju Delte i Brajdice tijekom 1940-ih i 1950-ih godina, koji svjedoče o rastućem raskoraku između vizionarskog urbanizma i realnosti političkoekonomske konstelacije tih desetljeća.

KLJUČNE REČI: RIJEKA, DELTA, BRAJDICA, POSLIJERATNA ARHITEKTURA, POSLIJERATNI URBANIZAM, URBANA REGENERACIJA 